\section{Throwing money at biodefense}

\author{
US funding for biodefense research continues on an upward trend, \\ but some say the effort is misguided. Laura DeFrancesco reports.
}

The ink was barely dry on the US FY 2004 budget in February when the Bush administration released its budget proposal for 2005, with record-setting increases in funding for biodefense-related research. Once again, the Department of Homeland Security (DHS; Washington, DC) is the big winner, with a $15 \%$ increase in funding; this follows on the heels of a 50\% increase in 2004 and makes the department one of the country's chief sources of funding for R\&D. Meanwhile, money for other research programs remains flat or has declined, so that defense-related research funding now accounts for more than half of the total federal research budget, outpacing that of nondefense research-a situation that has never occurred before ${ }^{1,2}$.

Included in the budget proposal is $\$ 2.8$ billion for Project BioShield-the Bush administration's program for procuring vaccines and diagnostics for potential bio-threats. However, industry people say BioShield doesn't have the protections that are needed to get them interested in biodefense. Critics worry about the quality of the products that will be rushed into production under the expedited review allowed under the terms of BioShield; others see it as a political ploy by the administration to lull the US public into a false sense of security ${ }^{3}$.

The likelihood of developing a dynamic 'biodefense industry' also appears remote.
Despite predictions that the billions of dollars being poured into R\&D would spawn a new industry ${ }^{4}$, not a single 'biodefense' company has so far been created. This has not stopped small biotech companies from taking the government's money, however-a factor that might have helped cash-strapped companies make it through recent lean years. But critics wonder whether the money is being divided up into too many pieces and whether, despite the billions handed out, the United States is really any better prepared for a bioterrorist attack than it was three years ago. In a report issued in January, the Institute of Medicine (Washington, DC) called for the creation of an umbrella agency to coordinate the government effort, claiming that the current program is fragmented and underfunded, offering "dismal prospects for successful results" 5 .

\section{A new attitude}

The US government has been in the business of biodefense for a long time, but since 9/11, its commitment has taken on different proportions. Not only has overall funding for biodefense-related research and development risen dramatically (Fig. 1), but where federal biodefense research was once almost exclusively the charge of the Department of Defense (DoD; Arlington, VA), now ten different government agencies are involved in

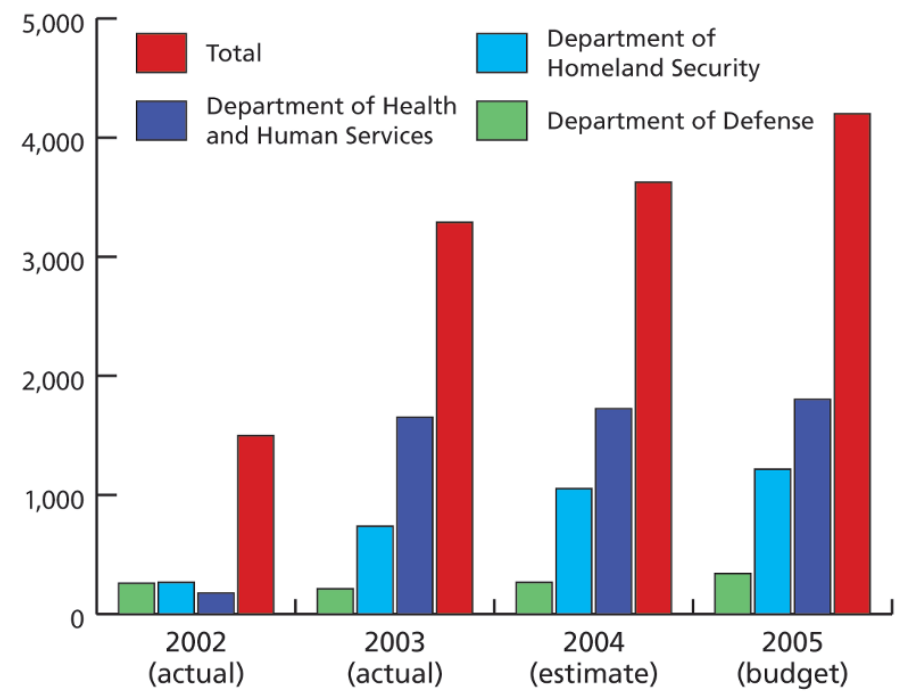

Figure 1 Historical data on funding of biodefense R\&D by selected agencies. (Source: K. Koizumi.) the effort (Table 1). Although the DHS is nominally in charge, some question its ability to manage technology development, and it has already started giving back pieces to other agencies better equipped to deal with the complex business of research ${ }^{6}$. Furthermore, the National Institutes of Health (NIH; Bethesda, MD), the recipient of the largest share of the pie, has made the unprecedented move of funding product development and manufacturing, something that in the past was left to industry.

In this new era of bioterrorism, a new approach to biodefense has emerged as well. The emphasis is shifting away from vaccines, the cornerstone of past biodefense projects, toward developing broad-spectrum therapies and technologies and gaining a better understanding of natural immunity. The recent spate of new and deadly infectious diseases and strains such as severe acute respiratory syndrome (SARS) and avian flu, not to mention recent bioterrorist attacks in the United States involving anthrax and ricin, have taught us that it is impossible to predict what scourges we might be facing next. Placing bets by developing single-purpose vaccines is risky; they might never be needed or they might become obsolete before they make it through production.

Leading the US government's research effort is, appropriately, the National Institute of Allergy and Infectious Diseases (NIAID; Bethesda, MD), which has a $\$ 1.4$ billion budget for fiscal year 2004, increased 17\% over last year's-this at a time when other institutes saw rises in the 3-4\% range (Fig. 2).

And although it's too soon for new therapies to have made it through development, NIAID director Anthony Fauci points to progress in numerous areas. For one thing, his institute has provided $\$ 350$ million in funds to establish nine Regional Centers of Excellence for Biodefense and Emerging Infectious Diseases Research and $\$ 85$ million for five Cooperative Centers for Translational Research on Human Immunology and Defense, in addition to funding eight new regional and two national containment laboratories (for a list of centers, go to: http://www.niaid.nih. gov/biodefense/research/resources/htm). Without the proper facilities, this dangerous work could not go on, says Fauci, whose own agency will be soon sporting a new integrated research facility, Building 33 .

In addition, the NIAID funded well over a hundred biodefense related projects in 2003, and has given out contracts to start stockpiling therapies for anthrax. Among the NIAID grants awarded so far are those for platforms that nonspecifically boost the immune 


\begin{tabular}{lrrr} 
Table 1 US homeland security research and development by agency & \\
Agency & $\begin{array}{c}\text { FY 2004 } \\
\text { (estimated; millions) }\end{array}$ & $\begin{array}{c}\text { FY 2005 } \\
\text { (budget; millions) }\end{array}$ & $\begin{array}{c}\text { Percentage } \\
\text { change }\end{array}$ \\
\hline Agriculture & $\$ 39$ & $\$ 262$ & $566 \%$ \\
Commerce & $\$ 24$ & $\$ 24$ & $2.1 \%$ \\
Defense & $\$ 267$ & $\$ 340$ & $27.4 \%$ \\
Energy & $\$ 47$ & $\$ 68$ & $43.9 \%$ \\
Homeland Security & $\$ 1053$ & $\$ 1216$ & $15.5 \%$ \\
Environmental Protection & $\$ 60$ & $\$ 31$ & $-48.1 \%$ \\
Health and Human Services & $\$ 1,725$ & $\$ 1,804$ & $4.6 \%$ \\
National Aeronautics and Space Administration & $\$ 65$ & $\$ 55$ & $-15.4 \%$ \\
National Science Foundation & $\$ 308$ & $\$ 317$ & $2.9 \%$ \\
Transportation & $\$ 3$ & $\$ 2$ & $-7.7 \%$ \\
Other & $\$ 34$ & $\$ 80$ & $136 \%$ \\
Total & $\$ 3,626$ & $\$ 4,200$ & $15.9 \%$ \\
\hline Source: Kei Koizumi. & & &
\end{tabular}

\section{Small-business biodefense}

response (p. 387) for and technologies that can be easily extrapolated to new pathogens. The beauty of his program as a whole, Fauci says, is that "it's designed to be able to be translated back and forth from those diseases not deliberately released to those that are."

With the NIH required to spend $2.5 \%$ of its research budget on small-business grants through the Small Business Innovation Research (SBIR) and Small Business Technology Transfer (STTR) programs, as the biodefense budget grows, so do the SBIR and STTR budgets. With a biodefense research budget of over a billion dollars, the small-business program is looking at $\$ 40$ million per year for biodefense grants alone. In addition, according to Greg Milman, director of the Office for Innovation and Special Projects at the NIAID, the SBIR program has been evolving to

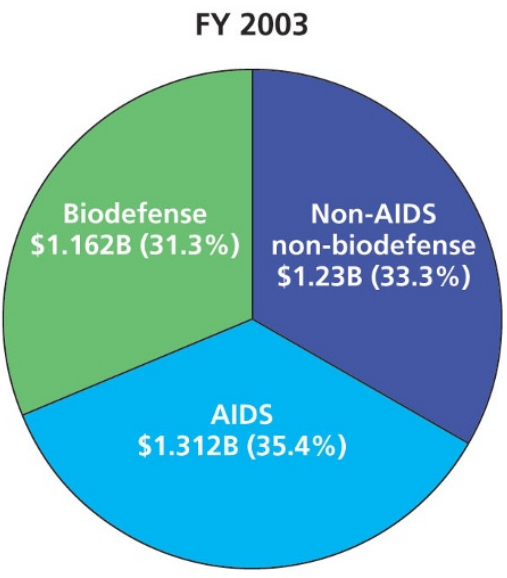

$\$ 3.706 B$

increase the likelihood that promising products will make it to the marketplace. Even before biodefense entered the picture, the program had already started to stretch its funding terms and amounts to allow more advanced technology development-increasing the term of phase 1 grants from six months to two years, and from $\$ 100,000$ to $\$ 300,000$ per year. Similarly, phase 2 grants have increased under the advanced technology guidelines from two to three years and from $\$ 750,000$ to $\$ 1$ million annually.

However, there's still the question of what happens to those products after a few years of SBIR funding, because even at its best ( $\$ 3$ million over three years), the funding is not sufficient to bring a drug through development. SBIR has therefore instituted a new competitive renewal program specifically for phase 2 projects that have products moving toward Food and Drug Administration (FDA;

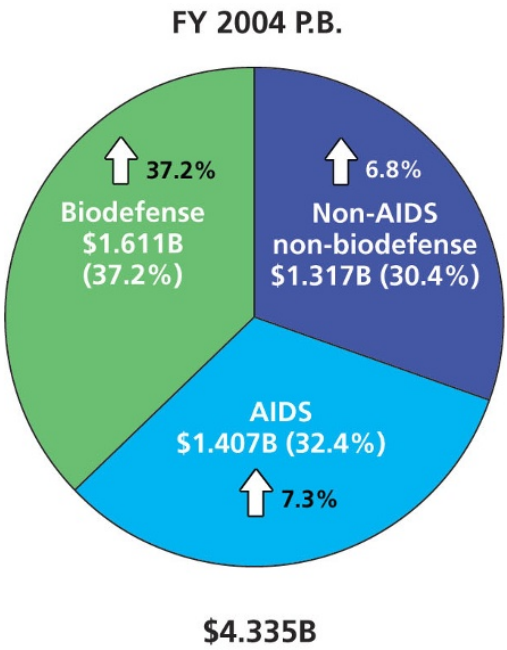

Figure 2 NIAID budget comparison: FY 2003 to FY 2004, president's budget. (Source: NIAID.)
Rockville, MD) approval. The goal is to keep the most promising products moving forward until private funds or federal money (such as that available through Project BioShield, discussed below) becomes available.

Milman says the response from industry has been overwhelming, and he sees at least two good reasons for interest in this area, despite the lack of a definable market. First, the funding provides companies with an opportunity to develop platforms that may find applications outside the biodefense arena. He points to the dozens of antiviral agents that came into being as a consequence of the influx in funding for AIDS therapies in the 1980s and 1990s. Second, Milman says, working on the national defense is good for a company's public image. "It will look good to stockholders, and to the public," he explains.

\section{Road to perdition}

Though \$1.4 billion may seem like a lot of money, considering that it can cost anywhere between $\$ 500$ million and $\$ 1$ billion to bring a single drug to market, NIH clearly can't do it all. Enter Project BioShield-the Bush administration's answer for ensuring that therapies are produced and available to the public should they ever be needed. As outlined in Bush's 2003 State of the Union address, BioShield, in addition to providing funding, establishes mechanisms for indemnification and expedited review in times of crisis, and relaxes thresholds and procedures for government contracts (see Box 1).

Sound good? Not to the biopharmaceutical industry, which sees a number of areas that need improving. A key issue is liability, according to Gillian Woollett, vice president for science and regulatory affairs at the Biotechnology Industry Organization (BIO; Washington, DC). Woollett says industry objects to the fact that companies would be protected only during a crisis (who determines when there is a crisis?) and wants blanket indemnification. Then there's time. BioShield will pay for drugs five years out from FDA approval. As drugs can take over a decade to develop, this isn't long enough, some say. And finally, industry wants no barriers on what products qualify for BioShield funding. The current bill specifies that funding can be applied only to those products expressly designed for defense purposes-in other words, no dual use. The government doesn't want to foot the bill for products with commercial potential in the private marketplace. However, Woollett points out that the most immediate way to get drugs in the 


\section{Box 1 BioShield basics}

The BioShield program outlines three main themes for procuring vaccines and diagnostics against potential bio-threats.

Spending authority for the delivery of nextgeneration medical countermeasures:

- Creation of a permanent indefinite funding authority to spur the development of medical countermeasures

- Permission for government to purchase vaccines and other therapies as soon as the experts believe they can be made safe and effective

New NIH programs to speed research and development of medical countermeasures:

- Increased authority and flexibility for NIAID director to award contracts and grants for R\&D of medical countermeasures

- Permission for more rapid hiring of technical experts and procurement of items necessary for research
New FDA emergency-use authorization (supplementing the traditional FDA licensing process) for promising medical countermeasures under development:

- Permission for emergency use of agents still under formal FDA review at the time of an attack that experts have judged to be safe and effective even though they have not yet completed the format FDA process, to permit effective use of such treatments if alternatives are not available

- Authority restricted to drugs under the direct control of the US government, and requires $\mathrm{HHS}$ and FDA determination that the drugs were expected to have benefits in the emergency situation that outweighed expected risks.

Source: The White House: President Details Project BioShield (press release, 3 February 2003). pipeline is to leverage off existing technologies. Currently, it's not clear that such products would qualify.

And then there's the issue of how much the government is willing to pay. After the Cipro debacle during the 2001 anthrax crisiswhen Department of Health and Human Services director Tommy Thompson threatened to void the patent on the anthrax drug ciprofloxacin if Bayer didn't lower its price to roughly half of what the government was paying-industry is more cautious about going into business with the government. Una Ryan, CEO of Avant Immunotherapies (Needham, MA), sums it up: "There's not enough money, not enough time and not enough sweeteners."

\section{Where in the world is BioShield?}

Three versions of BioShield are working their way through the US Congress. The House of Representatives overwhelmingly passed one version (HR2122), but the Senate version (S1504) is being held up for unexplained reasons. Staffers in the office of Senator Judd Gregg (R-NH), sponsor of the bill, say they expect it to pass "sometime this year."

Meanwhile Senators Joseph Lieberman (D-CT) and Orrin Hatch (R-UT) have introduced a third bill (S666) designed to create a biodefense industry as distinct from a purely government-supported endeavor. Believing that efforts by the federal government to contract production of countermeasures have failed in the past and will continue to do so, Lieberman and Hatch designed a bill that provides incentives for the private sector to step in and become engaged in biodefense research, including tax credits for companies willing to raise capital to do biodefense research, and intellectual property protections that are missing from the Senate bill. According to Lieberman staffer Chuck Ludlum, the Lieberman-Hatch bill puts the risk as well as the rewards in the hands of industry, and sets up competition among companies so that only the best products will receive government support. As such, the bill is not receiving industry support, and it is unlikely to pass.
While this is playing out in the US Congress, the Bush administration tacked $\$ 2.5$ billion onto the 2004 Homeland Security Appropriations bill for BioShield projects. Without the legislation, however, there are no guidelines as to what the money will be spent on, who will make the decisions and how it will be allocated. According to Mark Dibner, president of the consulting group BioAbility (Research Triangle Park, NC), this has led to "confusion and ignorance." Institute directors have no idea just how much money they will have available and when they will have it, delaying implementation.

Although industry acknowledges that the administration of BioShield funding is imperfect, they are making the most of BioShield in its current, flawed form. "Better to get started, and show what they can do, and then go back for more money and the time to do it right," says Ryan.

\section{Biotechnology industry response}

The recipients of the government's largess include numerous biotech companies. According to a study done by the web newsletter GenomeWeb last October, biotech companies received about $30 \%$ of the $\$ 60.4$ million in grant money given out in 2003 (ref. 7). But don't look to them any time soon for new products. Without the promise of guaranteed purchase, that is to say without BioShield, small companies often can't risk, and many simply don't have, the hundreds of millions of dollars it takes to move even a proven product through development and testing.

But some progress is being made. Human Genome Sciences (Rockville, MD), for example, has reported that its monoclonal antibody against anthrax protects mice and monkeys from inhalation anthrax, the most deadly form of the disease-representing a

\section{Box 2 European rapid responses?}

Although Europe has not responded to the threat of bioterrorism with the same alacrity as the United States, governments appear to be taking lessons from the United States. In March, the European Commission (Brussels) received a report, Research for a Secure Europe: Report of the Group of Personalities in the Field of Security Research, which provides a glimpse into European thinking ${ }^{8}$.

On the basis of calculations of US spending per citizen, this group recommends a $€ 2$ billion per year investment in research for security, though acknowledging that it may take a few years to get to this point. Although not wishing to duplicate the efforts of researchers in other parts of the world, it also does not want to concede the competitive edge to the United States.

But the seemingly leisurely pace of their response seems to ensure that the United States will indeed remain in the lead. The report called for a European Community-funded European Security Research Program to be launched by 2007. 
project that, interestingly enough, the company undertook with its own money. According to Jim Davis, HGS's executive vice president, the few hundred thousand dollars they might have received from a grant was not going to make a difference. However, the next stage, manufacturing the drug for testing, will be costly, and this is something the company is not willing to take on without a guarantee of purchase.
HGS is not alone. Coley Pharmaceuticals (Wellesley, MA) CEO Robert Braztler says his company has a broad-spectrum antiinfective ready for phase 3 trials, but won't be doing them without government funding. He says that the way the money is being divvied up into hundreds of small grants is not going to be productive: what the government will end up with is only "the low-hanging fruit."
And clearly the money won't be coming from the private sector. Biotech analyst Alexander Hittle (AG Edwards, New York, NY) says that the investment community is cautious about biodefense. Given a choice between funding defense or cancer products, cancer will win every time.

\section{Peculiarly American?}

Although the biodefense funding largess will provide enormous benefits for those who can fit themselves into the biodefense enterprise, not everyone is embracing biodefense. Some question whether we need to be spending such vast sums of money on a largely hypothetical threat. Communities are protesting the construction of biocontainment facilities in their midst, fearing the proximity of dangerous pathogens. And the whole notion of national biodefense seems to be peculiarly American, as no other countries are engaging in this particular brand of research. In fact, the European Commission does not seem to feel the same sense of urgency, having put off setting up an agency to oversee biodefense research until 2007 (Box 2).

However, NIAID's Fauci remains optimistic that the funding will have enormous payoffs both within and outside the sphere of biodefense. He acknowledges that some members of the biopharmaceutical industry are taking a 'wait and see' attitude, though he says others are confident that this new level of interaction between government and industry is going to work and have already "stepped up to the plate." "Everyone is at least on notice that this is a new day," he says.

Laura DeFrancesco is Senior Editor at Nature Biotechnology.

1. Koizumi, K. Research Holds, Development Gains in 2005 Budget. AAAS Analysis of R\&D in the FY 2005 Budget (American Association for the Advancement of Science, Washington, DC, 5 March 2004).

2. Koizumi, K. Congressional Action on Research and Development in the FY 2004 Budget (American Association for the Advancement of Science, Washington, DC, USA, 2004).

3. Williams, M. The looming threat. Acumen J. Sci. 1, 40-50 (2003).

4. Medical Follow-up Agency, Institute of Medicine, Board of Life Sciences. Giving Full Measure to Countermeasures: Addressing Problems in the DoD Program to Develop Medical Countermeasures Against Biological Warfare Agents (National Academies Press, Washington, DC, USA, 2004).

5. Burrill, G.S. Biotech 2003. Life Sciences: Reevaluation and Restructuring (Burrill \& Company, San Francisco, USA, 2003).

6. Fox, J.L. US budget emphasizes bioterrorism countermeasures. Nat. Biotechnol. 22, 256-257 (2004).

7. Moser Jones, M. Say anthrax, or who got what in NIH FY 2003 grants for biodefense and category A pathogens. GenomeWeb News, 24 October 2003 (http://www.genomeweb.com/).

8. Schmitt, B. Research for a Secure Europe. GOP Draft (EU Institute for Security Studies, Paris, 2 February 2004). 